\title{
Chemical composition and antimicrobial activity of essential oils from Aframomum citratum, Aframomum daniellii, Piper capense and Monodora myristica
}

\author{
Sylvie Carolle Meffo Dongmo ${ }^{1}$, Jean-De-Dieu Tamokou ${ }^{1 \#}$, Guy Sedar Singor Njateng ${ }^{1}$, \\ Pierre Tane ${ }^{2}$ and Jules-Roger Kuiate ${ }^{1^{*}}$ \\ ${ }^{1}$ Research Unit of Microbiology and Antimicrobial Substances, Faculty of Science, University of Dschang, \\ P. O. Box 67 Dschang, Cameroon. \\ ${ }^{2}$ Research Unit of Natural Products Chemistry, Faculty of Science, University of Dschang, P. O. Box 67 Dschang, \\ Cameroon.
}

Received 4 April, 2019; Accepted 6 May, 2019

\begin{abstract}
This study was initiated to evaluate the chemical composition and in vitro antimicrobial activity of essential oils from four Cameroonian spices and to determine the therapeutic effect of a cream based on essential oil from Aframomum citratum. Essential oils were extracted from seeds by hydrodistillation and analyzed by gas chromatography coupled with mass spectrometry (GC/MS). The broth microdilution method was used for the minimum inhibitory concentration (MIC) and minimum microbicidal concentration (MMC) determinations. The therapeutic effect of a cosmetic cream based on essential oil from $A$. citratum seed $(1.25,2.5$ and $5 \% \mathrm{w} / \mathrm{w})$ was evaluated against dermatosis induced with a Methicillin-Resistant Staphylococcus aureus (MRSA) in rats. The main identified compounds in the essential oils are geraniol for A. citratum; eucalyptol, $\alpha$-terpineol and geraniol for Aframomum daniellii; $\beta$-pinene, germacrene $D$, trans- $\beta$-caryophyllene, $\alpha$-pinene, naphthalene and sabinene for Piper capense; $\alpha$-phellandrene, germacradienol and $\delta$-cadinene for Monodora myristica. Essential oil of $A$. citratum (MIC $=8-4096 \mu \mathrm{g} / \mathrm{ml}$ ) was the most active against bacteria and fungi, following in decreasing order by those of $A$. daniellii, $P$. capense and $M$. myristica. The antibacterial activity of the essential oil of $A$. citratum against MRSA and Escherichia coli S2(1) (MIC $=8 \mu \mathrm{g} / \mathrm{ml}$ ) was higher than that of amoxicillin used as reference drug (MIC $=128-256 \mu \mathrm{g} / \mathrm{ml}$ ). The combination of essential oils of $A$. citratum and $A$. daniellii (1:1) displayed a synergistic effect. The cream based on essential oil of $A$. citratum $(5 \%)$ and Baneocin (reference drug) eradicated the dermatosis induced with MRSA in rat after two weeks of treatment. These results indicate that the tested essential oils possess antimicrobial activities which could be a function of either the individual or the additive effects of the identified phytoconstituents.
\end{abstract}

Key words: Spices, hydrodistillation, essential oils, gas chromatography/mass spectrometry (GC/MS), antibacterial, antifungal, synergistic effect.

\section{INTRODUCTION}

The skin can be infected by different types of microorganisms, most often by Gram-positive bacteria such as Staphylococcus species. Bacterial skin infections are widespread all over the world and many are caused by Staphylococcus aureus. The treatment of $S$. aureus infection, particularly Methicillin-Resistant $S$. aureus 
(MRSA), is a challenge in clinical practice (Malachowa et al., 2013; Song et al., 2017).

In developing countries, the main difficulties that accompany their treatments with conventional medicines are the high cost and toxic effects of the common antibiotics, as well as the development of multi-resistant pathogenic microorganisms to the treatments (Yang et al., 2016). Complementary and alternative medicines (CAMs) are used by $60-80 \%$ of developing countries and are also the most widespread sources of medicines in the world (Lee et al., 2012). Indeed, among all the CAMs, essential oils represent the most popular choices for the treatment of fungal skin infections (Millikan, 2002) and one of their main applications is their use in dermatology (Reichling et al., 2009).

Essential oils are primarily used as natural preservatives, flavorings and fragrances in cosmetic products (Fernandes et al., 2013). They are potential sources of antioxidants and natural antimicrobials, in addition to their multiple properties such as antiparasitic, analgesic and cytotoxic properties (Mith et al., 2014).

Among the potential sources of essential oils, spices have long been investigated because they contain volatile bioactive compounds that can be of interest in therapy and nutrition. Indeed, essential oils from medicinal spices and vegetables are important sources of antimicrobial agents in addition to their ability to stimulate the digestive system (Rahman et al., 2011). Medicinal spices and vegetables have traditionally been used as food additives, coloring, flavoring and preservative agents as well as antiparasitic, antihelmintic, analgesic, expectorant, sedative, antiseptic and antidiabetic substances in many parts of the world (Rahman et al., 2011; Dzoyem et al., 2014).

Aframomum daniellii (Hook.f.) K. Schum belonging to Zingiberaceae family is a large, robust, perennial plant that is about 3-4 m tall and is usually found under shades in plantations near riverine areas. Its seeds are used for flavouring traditional dishes as well as food additives, laxative, anti-helmintic, antibacterial and antifungal agents. The rhizome juice of this plant is effective in the treatment of body odor and toothache (Pamela et al., 2016). The leaves and seeds are used in the treatment of internal and external piles (Focho et al., 2009). This plant is also used in traditional food preparations for its flavoring, coloring and preservative properties (Tajkarimi et al., 2010), as well as to cure malaria, dysentery, dysmenorrhea, infertility, rubella, leprosy and cancers (Titanji et al., 2008).

Aframomum citratum (Zingiberaceae) $\mathrm{K}$. Schum is a perennial herbaceous producing leafy stems up to 3 meters tall from a rhizomatous rootstock (Burkil, 2000). Young shoots are eaten as a vegetable while the seeds are eaten as a spice in Cameroon. The plant is traditionally used as an aphrodisiac and also to treat bacterial infections, malaria and cancers (Titanji et al., 2008; Kuete et al., 2011).

Piper capense Lin. f (Piperaceae), known as long black pepper, is an endemic plant of East Africa found in wet highlands where it is produced traditionally for human consumption and medical uses (Kokwaro, 1976; Van Wyk and Gericke, 2000).

M. myristica (Gaertn) Dunal is a perennial edible plant of the Annonaceae family. It is mostly found in the humid tropical forests of West and Central Africa and commonly known as African nutmeg and calabash nutmeg. The seeds of this plant are used to cure constipation, uterine hemorrhage, diuretic and fever (Dzoyem et al., 2014). Some biological activities such as cytotoxic, antiprotozoal, antibacterial, anti-inflammatory and antioxidant activities have been documented for $A$. citratum, A. daniellii, P. capense and M. myristica (Kuete et al., 2011; Dzoyem et al., 2014).

However, from literature search, no scientific investigations have been conducted till date to verify the in vivo antimicrobial activities of the above plant species and there is a paucity of data on their essential oil composition. This work was therefore carried out to evaluate the chemical composition and in vitro antimicrobial activity of essential oils from the seeds of A. citratum, A. daniellii, $P$. capense and M. myristica as well as to determine the therapeutic effect of a cream based on essential oil from $A$. citratum.

\section{MATERIALS AND METHODS}

\section{Plant materials}

Dried seeds of $A$. citratum, $A$. daniellii, $P$. capense and M. myristica were purchased in February 2016 at market "B" in Bafoussam, situated in the Western region of Cameroon. The plant species were identified using their seeds by Mr. Fulbert TADJOUTEU, a Botanist of the National Herbarium of Cameroon by comparison with specimens whose voucher numbers were $37736 / \mathrm{HNC}$, 43130/HNC, 6018/SRF/NHC and 2949/SRF/NHC for $A$. citratum, $A$. daniellii, $P$. capense and $M$. myristica, respectively.

\section{Extraction of essential oils}

The essential oils were obtained by hydrodistillation using a Clevenger-type apparatus. $500 \mathrm{ml}$ of distilled water was separately added to seeds of $A$. citratum (100 g), A. daniellii $(100 \mathrm{~g}), P$. capense $(200 \mathrm{~g})$ and $M$. myristica $(200 \mathrm{~g})$. A magnetic stirrer was introduced in the apparatus and the mixture was heated on a hot plate. Hydrodistillation was carried out for $6 \mathrm{~h}$ with $A$. citratum and $A$. daniellii and for $1 \mathrm{~h}$ with $P$. capense and $M$. myristica. The essential oils were dried over a column of anhydrous sodium sulphate (Sigma-Aldrich, St. Louis, MO, USA) and then stored in

*Corresponding authors. E-mail: jrkuiate@yahoo.com; jtamokou@yahoo.fr

Author(s) agree that this article remain permanently open access under the terms of the Creative Commons Attribution License 4.0 International License 
amber tubes at $4^{\circ} \mathrm{C}$ until analyses.

\section{Determination of the chemical composition of essential oils}

The essential oils were analyzed by gas chromatography coupled with mass spectrometry (GC/MS), using an Agilent apparatus (6890 $\mathrm{N}$ series), fitted with a HP-5MS fused silica capillary column $(30 \mathrm{~m} \times$ $0.25 \mathrm{~mm}$, film thickness $0.25 \mu \mathrm{m}$ ) and coated with $5 \%$ phenyl $95 \%$ dimethylpolysilosane. The initial temperature was set at $50^{\circ} \mathrm{C}$ and the oven was heated up to $110^{\circ} \mathrm{C}$ at a rate of $3^{\circ} \mathrm{C} / \mathrm{min}$, then from 110 to $300^{\circ} \mathrm{C}$ at a rate of $10^{\circ} \mathrm{C} / \mathrm{min}$. The carrier gas was pure helium at a flow rate of $1.2 \mathrm{ml} / \mathrm{min}$. The injector temperature was $250^{\circ} \mathrm{C}$, applying the split ratio of $1: 5$. Mass spectra were obtained using electron ionization source at $70 \mathrm{eV}$. Ion source temperature was maintained at $230^{\circ} \mathrm{C}$ and the mass range was $\mathrm{m} / \mathrm{z} 40-400 \mathrm{u}$. A scan interval of $0.5 \mathrm{~s}$ and fragments from 40 to $550 \mathrm{Da}$ were maintained. The essential oil was solubilized in pentane at concentration of $2 \mathrm{mg} / \mathrm{ml}$ and $1 \mu \mathrm{l}$ was injected on the chromatographic system. The relative quantity of the compounds present in the essential oils was expressed as a percentage based on the peak area produced in the chromatogram. From the obtained chromatograms, retention indices (RI) of components were determined relatively to the retention times of a series of $n$ alkanes $\left(\mathrm{C}_{8}-\mathrm{C}_{40}\right)$ with linear interpolation. Compounds were identified by comparing their retention indices and their mass spectra with those of Wiley Library data 2009.

\section{Microorganisms}

The used microorganisms in this study included fungal and bacterial species involved in skin infections and wound contaminations. These microorganisms included reference strains from American Type Culture Collection and clinical isolates. Fungal strains were made of two dermatophytes: Microsporum gypseum E1420 and Trichophyton violaceum obtained from Ecole Nationale Vétérinaire d'Alfort in France; seven yeast strains: Candida albicans ATCC 1663, C. albicans ATCC 9002, C. albicans IS1, Candida parapsilosis ATCC 22019, Candida tropicalis ATCC 750, Candida krusei ATCC6258, Cryptococcus neoformans IP90526; four amphotericine $\mathrm{B}$ and nystatin sensitive Candida spp isolates: Candida krusei, Candida parapsilosis, Candida lipolithica and Candida haemophilus; twenty amphotericine $\mathrm{B}$ and nystatin resistant isolates of $C$. albicans: $\mathrm{Ca}$ Da11, Ca E01, Ca F021, Ca F045, Ca K42, Ca D10, Ca F066, Ca F005, Ca F017, Ca F057, Ca K14, Ca F015, Ca F023, Ca F040, Ca F002, Ca F041, Ca K072, $\mathrm{Ca}$ F049, Ca F026, Ca K22 and eight nystatin resistant isolates of C. neoformans: CN, CN169, CN173, CN047, CN091, CN046, CN 096, CN158, obtained from Pasteur Institute (IP, Paris-France). Bacteria were constituted of eight Gram-positive species: $S$. aureus ATCC 25923, methicillin resistant $S$. aureus MRSA03, methicillin resistant $S$. aureus MRSA04, methicillin sensitive $S$. aureus MSSA01, Staphylococcus aureus ST120, Enterococcus aerogenes ATCC 13048, Enterococcus aerogenes and Enterococcus adecarboxylate and eight Gram-negative bacteria: Escherichia coli ATCC 10536, Escherichia coli, entero-aggregative Escherichia coli, Pseudomonas aeruginosa ATCC 27853, Pseudomonas aeruginosa PA01, Bacillus subtilis, Klebsiella pneumoniae ATCC2513883, Shigella flexneri obtained from our laboratory collection. The bacteria and yeasts were maintained at $+4^{\circ} \mathrm{C}$ on agar slants.

\section{Experimental animals}

In this study, 42 Wistar albino rats (21 males and 21 females; $10-12$ weeks old; $150-200 \mathrm{~g}$ ) were used. They were bred in the animal house of the Department of Biochemistry, University of Dschang,
Cameroon. The animals were fed with a standard diet. Food and water were given ad libitum to all animals used for the experiments. Animals were maintained at room temperature $\left(22 \pm 2^{\circ} \mathrm{C}\right)$. The study was conducted according to the ethical guidelines of Committee for Control and Supervision of Experiments on Animals (Registration no. 173/CPCSEA, dated 28 January, 2000) Government of India, on the use of animals for scientific research.

\section{Determination of the minimum inhibitory concentration (MIC) and minimum microbicidal concentration (MMC)}

MIC was determined by broth micro dilution method as previously described (Tamokou et al., 2009; Fogue et al., 2012) with slight modifications. The microbial inocula were prepared from $24 \mathrm{~h}, 48 \mathrm{~h}$ and 7 days old broth cultures from bacteria, yeasts and dermatophytes, respectively. The absorbance was read at $600 \mathrm{~nm}$ (for bacteria), $530 \mathrm{~nm}$ (for yeasts) and $450 \mathrm{~nm}$ (for dermatophytes) using a spectrophotometer (Jenway ${ }^{\mathrm{TM}} 6305$ UV/Visible Spectrophotometer, Fisher scientific, UK).

From the prepared microbial solutions, other dilutions with sterile physiological solution were prepared to give a final concentration of $2 \times 10^{5}$ colony-forming units (CFU)/ml for bacteria and $2 \times 10^{5}$ spores $/ \mathrm{ml}$ for yeasts and dermatophytes. Stock solutions of essential oils were prepared in 5\% tween 80 at concentrations of 16.38 (for essential oils) and $2.04 \mathrm{mg} / \mathrm{ml}$ (for pure reference drugs). The antimicrobial susceptibility test was performed in a 96-well microplate. The twofold serial dilutions of test samples were made in Mueller Hinton Broth (MHB) (Conda, Madrid, Spain) for bacteria and Sabouraud Dextrose Broth (SDB) (Conda, Madrid, Spain) for yeasts and dermatophytes.

The final concentrations ranged from 4.096 to $0.032 \mathrm{mg} / \mathrm{ml}$ for the essential oil and from 128 to $0.50 \mu \mathrm{g} / \mathrm{ml}$ for the reference drugs. For every experiment, a sterility check ( $5 \%$ tween 80 and medium), negative control ( $5 \%$ tween 80 , medium and inoculum) and positive control ( $5 \%$ tween 80 , medium, inoculum and reference drug) were included. The plates were covered with the sterile sealer and incubated at $35^{\circ} \mathrm{C}$ for $24 \mathrm{~h}$ (for bacteria) and $48 \mathrm{~h}$ (for yeasts). Dermatophytes were incubated at $27^{\circ} \mathrm{C}$ for 5 days. Bacterial growth was monitored colorimetrically using iodotetrazolium chloride (INT). Viable bacteria change the yellow dye of $\mathrm{p}$-iodonitrotetrazolium violet to a pink color. Yeasts and dermatophytes growth in each well was determined by observing and comparing the test wells with the positive and negative controls. The absence of microbial growth was interpreted as the antibacterial or antifungal activities. The MIC was the lowest concentration of the essential oil that prevented change in color or visible growth of micro-organisms.

Minimum Bactericidal Concentrations (MBCs) and Minimum Fungicidal Concentrations (MFCs) were determined by adding $50 \mu \mathrm{l}$ aliquots of the well (without INT), which did not show any microbial growth after incubation during MIC assays, into $150 \mu \mathrm{l}$ of essential oil-free Mueller Hinton Agar (for bacteria) and Sabouraud Dextrose Agar (for yeasts and dermatophytes). MBCs or MFCs were defined as the lowest concentration yielding negative growth. All the experiments were performed in triplicate. Amoxicillin, nystatin and griseofulvin were used as positive controls for bacteria, yeasts and dermatophytes, respectively.

\section{In vivo antibacterial assay}

The in vivo antibacterial activity was determined with the essential oil of $A$. citratum seed which displayed the most in vitro antimicrobial activity.

\section{Formulation of cosmetic cream}

Cosmetic cream was made using the modified formula of Banker 
and Rhodes (1995). Two mixtures were prepared separately: mixture A made up of water (97.4\%), glycerol (1.7\%) and hydroxylpropyl-methyl-cellulose (HPMC) $(0.9 \%)$ and mixture B made up of wax $(15.1 \%)$, kernel oil $(82.9 \%)$ and shea butter $(2.0 \%)$. The two mixtures were mixed at $70^{\circ} \mathrm{C}$ in a water bath for $4 \mathrm{~min}$ and then cooled on ice bath for $2 \mathrm{~min}$, followed by addition of sodium benzoate $(1 \%)$ as cream preservative. Finally, $1.25,2.5$ and $5 \mathrm{~g}$ of essential oil of $A$. citratum were added to $100 \mathrm{~g}$ of cream to yield the final concentrations of oil in the cream of $1.25,2.5$ and $5 \%$ respectively. Control cream was made up of cream without any antibacterial and without essential oil.

\section{Bacterial infection induced with S. aureus MRSA03}

Prior to infection, rats were starved for $12 \mathrm{~h}$ and anesthetized using ketamine (100 mg kg-1 body weight) under sterile conditions. The dorsal fur of the animals was shaved with an electric clipper and the site of the infection ( $3 \mathrm{~cm}$ diameter) was outlined on the back of the animals using a marker pen, then disinfected with ethanol $95^{\circ}$ and abraded with sandpaper $\left(\mathrm{N}^{\circ} 120\right) 1 \mathrm{~min}$ before inoculation. Then, rats were inoculated at the site of infection with $10^{8} \mathrm{CFU} / \mathrm{ml}$ of Methicillin-Resistant $S$. aureus (MRSA) suspension prepared from an overnight culture (Kugelberg et al., 2005). One group was not infected and not treated (uninfected group). Infected rats were divided into six groups of three animals each (three control groups and three test groups). The first control group was not treated (untreated group), the second and third control groups received cream without essential oil (blank group) and Baneocin® (2\%) 250 $\mathrm{UI} / 5000 \mathrm{UI}$ (Baneocin group), respectively. The three other groups were treated with cream-based essential oil from seed of $A$. citratum at $5,2.5$ and $1.25 \%(\mathrm{w} / \mathrm{w})$, respectively. Treatment started $24 \mathrm{~h}$ after the establishment of the infection by dermal application of $0.1 \mathrm{~g}$ of cream-based on essential oil and Baneocin ${ }^{\circledR}$ once per day for 14 consecutive days.

\section{Evaluation of in vivo antibacterial activity}

The efficacy of the treatment was evaluated on a clinical and mycological basis. Clinical efficacy was based on changes observed at the site of infection during the test. These observations were based on measurements taken at the site of infection from two perpendicular lines drawn on the site and measuring on the one hand, the evolution of the inflammation (inflammation percentage) and on the other hand, the evolution of epithelialization (epithelialization percentage). These parameters were noted every three days.

$$
\text { Inflammation } \%=\frac{\text { Horizontal diameter }+ \text { Vertical diameter }}{2}
$$

Epithelialization $\%=\frac{\text { Horizontal diameter }+ \text { Vertical diameter }}{2}$

The epithelialization time, that is, the number of days required for the scar to fall off without residual gross injury, was determined as the epithelialization period (Ameri et al., 2013). For the mycological efficacy, animals were anesthetized with chloroform vapors at the end of the treatment and a skin sample $(4 \mathrm{~g})$ was taken, ground in a porcelain mortar in the presence of $4 \mathrm{ml}$ of physiological saline $(\mathrm{NaCl}) 0.09 \%)$ and the ground product obtained was centrifuged at $3000 \mathrm{rpm}$ for $15 \mathrm{~min}$. The supernatant obtained after centrifugation was decanted and used for culture on Mannitol Salt Agar medium in order to count the number of Colony Forming Units (CFU) of bacteria per gram of skin. Body weights of animals were measured before sacrifice. The organs (liver, kidneys, lungs, heart and spleen) were carefully dissected out, blotted, observed macroscopically and weighed immediately using a Sartorius electronic balance. The relative organ weight (ROW) of each animal was then calculated as follows:

ROW $=\frac{\text { Absolute organ weight }(\mathrm{g}) \times 100}{\text { Body weight of rat on day of sacrifice }(\mathrm{g})}$

\section{Statistical analysis}

Data were subjected to the one-way analysis of variance (ANOVA) and recorded as mean \pm standard deviation (SD) and where differences exist, means were compared using Waller Duncan test at 0.05 significant levels. All analyses were performed using the Statistical Package for Social Sciences (SPSS, version 12.0) software.

\section{Ethics}

The experiments were carried out observing the welfare of animals as recommended by World Health Organization (WHO). Moreover, all procedures involving animals were carried out in strict compliance with the rules and regulations of local Ethics Committee.

\section{RESULTS}

\section{Yield of extraction and chemical composition of essential oils}

The essential oils of $A$. citratum, $A$. daniellii and $M$. myristica were translucent with extraction yields of $1.0 \pm$ $0.1 \%, 1.1 \pm 0.1 \%$ and $2.4 \pm 0.5 \%$, respectively whereas that of $P$. capense seed was green with the extraction yield of $1.6 \pm 0.3 \%$. A total of 6 compounds were identified in the essential oil of $A$. citratum seeds (Table 1). These compounds were mainly composed of monoterpenes with a marked predominance of oxygenated monoterpenes (geraniol, 96.80\%) and the absence of sesquiterpenes. Eighteen compounds were identified in the essential oils of $A$. daniellii belonging mainly to oxygenated monoterpenes (Table 1). The essential oil of $A$. daniellii seed was predominantly constituted of eucalyptol $(48.8 \pm 9.9 \%)$, a-terpineol $(21.7$ $\pm 2.6 \%)$ and geraniol $(10.5 \pm 1.2 \%)$. A total of 25 compounds were identified in the essential oil of $P$. capense. The essential oil of this plant species was slightly more monoterpenic $(56.2 \pm 4.4 \%)$ than sesquiterpenic $(41.4 \pm 4.8 \%)$ and was mostly composed of hydrocarbonated compounds $(90.7 \pm 5.9 \%)$ than oxygenated compounds $(6.8 \pm 5.8 \%)$. The major compounds found in the essential oils of $P$. capense are $\beta$-pinene $(37.3 \pm 1.7 \%)$, germacrene $D(9.8 \pm 4.1 \%)$, trans- $\beta$-caryophyllene $\quad(8.8 \pm 3.8 \%), \quad \alpha$-pinene $\quad(8.6 \pm$ 
Table 1. Qualitative and quantitative compositions of essential oils from the studied spices.

\begin{tabular}{|c|c|c|c|c|c|}
\hline Compound & RI & A. citratum & A. daniellii & P. capense & M. myristica \\
\hline Monoterpenes & & $99.3 \pm 0.1$ & $93.3 \pm 2.4$ & $56.3 \pm 4.3$ & $79.3 \pm 2.8$ \\
\hline Monoterpene hydrocarbons & & $0.3 \pm 0.2$ & $3.2 \pm 1.1$ & $52.3 \pm 4.4$ & $74.6 \pm 3.0$ \\
\hline Ethylether & 689 & - & - & - & 0.9 \\
\hline$\alpha$-Thujene & 921 & - & - & - & $1.1 \pm 0.2$ \\
\hline a-Pinene & 927 & - & 0.5 & $8.1 \pm 0.9$ & $3.1 \pm 0.4$ \\
\hline Sabinene & 968 & - & - & $4.7 \pm 1.3$ & - \\
\hline$\beta$-Pinene & 971 & - & $2.2 \pm 0.3$ & $36.5 \pm 1.9$ & - \\
\hline Myrcene & 990 & - & - & - & $1.0 \pm 0.2$ \\
\hline$\beta$-Myrcene & 995 & $0.2 \pm 0.0$ & - & $0.7 \pm 0.1$ & $2.0 \pm 0.2$ \\
\hline a-Phellandrene & 1002 & - & - & - & $61.5 \pm 5.1$ \\
\hline ঠ-3-Carene & 1006 & - & - & $1.4 \pm 0.1$ & - \\
\hline p-Cymene & 1020 & - & - & - & $1 \pm 0.1$ \\
\hline Limonene & 1024 & - & $1.3 \pm 0.2$ & $1.5 \pm 0.5$ & $5 \pm 0.6$ \\
\hline 1,8-Cineole & 1027 & 0.3 & - & - & - \\
\hline Oxygen-containing monoterpenes & & $99.0 \pm 0.1$ & $90.1 \pm 3.4$ & $4 \pm 1.5$ & $4.7 \pm 1.0$ \\
\hline Eucalyptol & 1026 & - & $48.8 \pm 9.9$ & - & - \\
\hline Linalool & 1100 & $1.3 \pm 0.2$ & $2.6 \pm 0.7$ & $1.3 \pm 0.4$ & $2.8 \pm 0.2$ \\
\hline Linalyl propionate & 1164 & - & 0.7 & - & - \\
\hline 4-Terpineol & 1174 & - & $2.9 \pm 1.9$ & $1.5 \pm 1.2$ & - \\
\hline$\alpha$-Terpineol & 1188 & - & $21.7 \pm 2.6$ & - & $1 \pm 0.1$ \\
\hline Sabinol & 1200 & - & - & - & $1.1 \pm 0.3$ \\
\hline Geraniol & 1257 & $96.8 \pm 0.3$ & $10.5 \pm 1.2$ & - & - \\
\hline Geranial & 1274 & $0.3 \pm 0.05$ & 0.4 & - & - \\
\hline Bornyl acetate & 1288 & - & - & $1.8 \pm 0.3$ & - \\
\hline Geranyl acetate & 1388 & $0.5 \pm 0.1$ & $3.0 \pm 1.0$ & - & - \\
\hline Sesquiterpenes & & - & $3.8 \pm 2.1$ & $41.2 \pm .2$ & $18.9 \pm 3.3$ \\
\hline Sesquiterpene hydrocarbons & & - & $2.6 \pm 1.1$ & $34.3 \pm 4.2$ & $8.3 \pm 2.6$ \\
\hline a-Cubebene & 1357 & - & - & $0.5 \pm 0.05$ & - \\
\hline a-Copaene & 1380 & - & - & $0.6 \pm 0.1$ & - \\
\hline$\beta$-Cubebene & 1393 & - & - & $2 \pm 0.6$ & - \\
\hline Trans- $\beta$-caryophyllene & 1424 & - & $1.6 \pm 0.5$ & $6.5 \pm 1$ & - \\
\hline Santalen & 1425 & - & - & - & $1.3 \pm 0.3$ \\
\hline$\beta$-Selimene & 1460 & - & - & $1.1 \pm 0.1$ & - \\
\hline a-Amorphene & 1482 & - & - & $0.9 \pm 0.0$ & - \\
\hline Germacrene D & 1488 & - & - & $7.4 \pm 1.7$ & - \\
\hline a-Amorphene & 1500 & - & - & $2 \pm 0.7$ & 0.5 \\
\hline a-Muurolene & 1506 & - & - & - & $1.0 \pm 0.3$ \\
\hline Y-Cadinene & 1522 & - & $1.5 \pm 0.2$ & - & $1.9 \pm 0.4$ \\
\hline Naphthalene & 1524 & - & - & $10.7 \pm 0.4$ & - \\
\hline$\delta$-Cadinene & 1532 & - & 0.4 & $1.5 \pm 0.5$ & $4.2 \pm 1.0$ \\
\hline Germacrene B & 1570 & - & 0.7 & $2.4 \pm 0.05$ & - \\
\hline Oxygen-containing sesquiterpenes & & - & $1.7 \pm 0.4$ & $6.9 \pm 4.1$ & $10.6 \pm 0.8$ \\
\hline Octabicyclooctanol & 1350 & - & 0.4 & - & - \\
\hline Germacradienol & 1588 & - & - & - & $7.9 \pm 0.6$ \\
\hline Caryophyllene oxide & 1598 & - & $1.2 \pm 0.2$ & $1.2 \pm 0.2$ & - \\
\hline Guaicol & 1609 & - & - & $2.4 \pm 0.8$ & - \\
\hline t-Muurolol & 1659 & - & 0.7 & - & $1.4 \pm 0.1$ \\
\hline a-Amorphene & 1661 & - & - & 1.5 & - \\
\hline t-Muurolol & 1672 & - & - & $0.9 \pm 0.4$ & $1.3 \pm 0.2$ \\
\hline Azulene methanol & 1684 & - & - & $1.2 \pm 0.6$ & - \\
\hline
\end{tabular}

RI: Retention indice. 
$0.9 \%)$, naphthalene $(8.3 \pm 3.5 \%)$ and sabinene $(4.8 \pm$ $1.1 \%)$. Twenty compounds were identified in the essential oil of $M$. myristica belonging to monoterpenes $(84.8 \pm 6.3 \%)$ especially monoterpene hydrocarbons $(81.8 \pm 8.2 \%)$. The main compounds are $\alpha$-phellandrene $(61.5 \pm 5.1 \%)$, germacradienol $(7.9 \pm 0.6 \%)$ and $\delta$-cadinene $(4.2 \pm 1.1 \%)$.

\section{Antimicrobial activity of essential oils}

In this study, the antibacterial and antifungal activities of essential oils from the studied spices were evaluated using broth micro dilution method against pathogenic microorganisms including yeasts, dermatophytes, Grampositive and Gram-negative bacteria. The results summarized in Tables 2 to 4 showed that essential oils were active against the tested microorganisms with MIC values varying from 8 to $4096 \mu \mathrm{g} / \mathrm{ml}$. Essential oil of $A$. citratum was active against all the tested bacteria (100\%), while essential oils of $A$. daniellii, $P$. capense and $M$. myristica were active against only thirteen of the seventeen tested bacteria (76.5\%) (Table 2). Interestingly, the antibacterial activity of $A$. citratum was significant particularly against $S$. aureus MSSA01, B. subtilis and $E$. coli S2 $(\mathrm{MIC}=8 \mu \mathrm{g} / \mathrm{ml}$ and $\mathrm{MBC}=32 \mu \mathrm{g} / \mathrm{ml})$. E. coli EC136 and Klebsiella spp (clinical isolates) were the most resistant bacteria to the essential oils. The bactericidal effect of essential oils was observed with $A$. citratum, $A$. daniellii, $P$. capense and M. myristica essential oils on $11 / 17(64.70 \%), 8 / 17$ (47.05\%), 7/17 $(41.17 \%)$ and $6 / 17$ (35.29\%) of tested bacteria, respectively.

The results also showed that essential oils were active against the tested fungi with MIC values ranging between 32 and $4096 \mu \mathrm{g} / \mathrm{ml}$ (Table 3). Essential oils of $A$. citratum, $P$. capense, $A$. daniellii and $M$. myristica were active against all the fungal species (100\%), while essential oil of $A$. citratum was the most active. $C$. albicans ATCC 9002 was the most sensitive yeast $(\mathrm{MIC}=256-512$ $\mu \mathrm{g} / \mathrm{ml}$ ), whereas C. lipolithica (MIC $=512-4096 \mu \mathrm{g} / \mathrm{ml}$ ) was the most resistant yeast. The essential oils from the studied spices displayed different degrees of antifungal activity against $C$. albicans and Cryptococcus neoformans resistant isolates with MIC values ranging between 128 and $4096 \mu \mathrm{g} / \mathrm{ml}$ (Table 4).

The essential oils of $A$. citratum: 23/28 (82.14\%) were the most active followed in a decreasing order by those of A. daniellii: 13/28 (46.42\%), P. capense: $6 / 28(21.42 \%)$ and $M$. myristica: $6 / 28(21.42 \%)$. The combination of essential oils of $A$. citratum and $A$. daniellii (1:1) was active against $100 \%$ of the tested isolates, while the combination of essential oils of $P$. capense and $M$. myritica $(1: 1)$ was only active against $3 / 28(10.71 \%)$ of the tested isolates (Table 4). Moreover, the antifungal activity of the combination of essential oils of $A$. citratum and $A$. daniellii (1:1) was greater than that of these essential oils used alone. However, the combination of essential oils of $P$. capense and $M$. myritica (1:1) reduced their antifungal activities compared to those of these essential oils used alone. In general, the MFC and MBC values are fourfold lesser than the MIC values on the corresponding microorganism; suggesting that the tested essential oils have fungicidal / bactericidal effects.

\section{In vivo antibacterial activity}

The therapeutic effect of a cream based on essential of $A$. citratum, which was found to be the most active essential oil, was evaluated against dermatosis induced with a Methicillin-Resistant $S$. aureus (MRSA) in rats. Animals infected with $S$. aureus showed visible inflammation $24 \mathrm{~h}$ post infection, characterized by the redness and swelling of the skin at the sites of inoculation. The percentage of inflammation reduces progressively during the treatment untill it reaches at $0 \%$ after 15 days of treatment in male and female rats (Figure 1).

In male rats, the epithelialization times were 9 days with 1.25 and $5 \%$ of cream and uninfected group and 12 days for the other groups (Figure 2). In female rats, the epithelialization times were 6 days for the groups treated with 1.25 and $5 \%$ of cream; 9 days for the untreated group and 12 days for the other groups (Figure 2). These results indicate that rats treated with 1.25 and $5 \%$ of cream and Baneocin exhibited shorter epithelialization times than controls (untreated, uninfected and blank groups) and those treated with $2.5 \%$ of cream.

The results also show that treatment significantly $(p<$ 0.05 ) reduced the number of Colony Forming Units (CFU) of bacteria at the infection site (Figure 3). In male rats, the number of CFU of bacteria at the infection site comparable with those of uninfected group were noted with $5,2.5$ and $1.25 \%$ of cream based on essential oil from A. citratum and Baneocin after 14 days of treatment (Figure 3). In female rats, the number of CFU of bacteria at the infection site in the groups treated with $5 \%$ of cream based on essential of $A$. citratum and Baneocin were lower than those obtained in the uninfected group. These results suggest that $5 \%$ of cream based on essential of $A$. citratum and Baneocin may be used to treat methicillin resistant $S$. aureus dermatosis induced in rats. Cream without essential oil (blank treatment) has a number of CFU of bacteria at the infection site comparable to that of untreated group. Organ-to-body weight ratio, an index often used in toxicological evaluations, was not significantly altered by the treatments (Table 5).

\section{DISCUSSION}

Differences in the extraction yields were noted between 
Table 2. Antibacterial activities (MIC and MBC in $\mu \mathrm{g} / \mathrm{ml}$ ) of essential oils from the tested spices.

\begin{tabular}{|c|c|c|c|c|c|c|c|c|c|c|c|c|c|c|}
\hline \multirow{2}{*}{ Bacteria } & \multicolumn{3}{|c|}{ A. citratum } & \multicolumn{3}{|c|}{ A. daniellii } & \multicolumn{3}{|c|}{ P. capense } & \multicolumn{3}{|c|}{ M. myristica } & \multicolumn{2}{|c|}{ AMOX } \\
\hline & MIC & MBC & $\mathbf{R}$ & MIC & MBC & $\mathbf{R}$ & MIC & MBC & $\mathbf{R}$ & MIC & MBC & $\mathbf{R}$ & MIC & MBC \\
\hline S. aureus ATCC25923 & 4096 & $>4096$ & - & 8 & $>4096$ & - & 32 & $>4096$ & - & 4096 & $>4096$ & - & 1 & 2 \\
\hline S. aureus ATCC25923 & 1024 & $>4096$ & - & $>4096$ & - & - & 2048 & $>4096$ & - & 512 & $>4096$ & - & 0.5 & 2 \\
\hline S. aureus & 32 & 32 & 1 & 128 & 512 & 4 & 2048 & 4096 & 2 & 2048 & $>4096$ & - & 2 & 2 \\
\hline S. aureus MSSA01 & 8 & 32 & 4 & 32 & 128 & 4 & 256 & 256 & 1 & 512 & 4096 & 8 & 128 & 128 \\
\hline S. aureus MRSA03 & 64 & 512 & 8 & 512 & 512 & 1 & 1024 & 2048 & 2 & 1024 & 2048 & 2 & 32 & 32 \\
\hline S. aureus MRSA04 & 32 & 256 & 8 & 32 & 64 & 2 & 512 & 2048 & 4 & 512 & $>4096$ & - & 32 & 32 \\
\hline S. aureus ST120 & 2048 & $>4096$ & - & 2048 & $>4096$ & - & $>4096$ & $>4096$ & - & $>4096$ & - & - & 0.50 & 1 \\
\hline B. subtilis & 8 & 32 & 4 & 512 & 4096 & 8 & 8 & 64 & 4 & 1024 & 4096 & 4 & 4 & 4 \\
\hline E. coli ATCC10536 & 1024 & $>4096$ & - & 1024 & $>4096$ & - & 1024 & $>4096$ & - & 512 & $>4096$ & - & 0.5 & 1 \\
\hline E. coli EC136 & 2048 & $>4096$ & - & $>4096$ & - & - & $>4096$ & - & - & $>4096$ & - & - & 4 & 4 \\
\hline E. coli $\mathrm{S} 2(1)$ & 8 & 32 & 4 & 8 & 64 & 8 & 2048 & $>4096$ & - & 8 & 128 & 16 & 256 & 256 \\
\hline Entero-aggregative E. coli & 256 & 512 & 2 & 1024 & $>4096$ & - & 512 & $>4096$ & - & $>4096$ & - & - & 16 & 16 \\
\hline E. adecarboxylate & 1024 & 2048 & 2 & $>4096$ & - & - & $>4096$ & - & - & 1024 & $>4096$ & - & 32 & 32 \\
\hline E. aerogenes & 512 & 2048 & 4 & 512 & $>4096$ & - & 512 & $>4096$ & - & 2048 & 2048 & 1 & 2 & 4 \\
\hline P. aeruginosa ATCC27853 & 32 & 256 & 8 & 32 & 256 & 8 & 32 & 512 & 16 & 32 & 1024 & 32 & 4 & 4 \\
\hline Klebsiella spp & 512 & $>4096$ & - & $>4096$ & - & - & $>4096$ & - & - & $>4096$ & - & - & 32 & 32 \\
\hline Shigella flexneri & 256 & 1024 & 4 & 512 & 2048 & 4 & 1024 & 1024 & 1 & 512 & $>4096$ & - & 16 & 16 \\
\hline
\end{tabular}

MIC: Minimum inhibitory concentrations; MBC: Minimum bactericidal concentrations; R = MBC/MIC; AMOX: amoxicilline.

Table 3. Antifungal activities (MIC and MFC) of essential oils from the tested spices.

\begin{tabular}{|c|c|c|c|c|c|c|c|c|c|c|c|c|c|c|c|}
\hline \multirow{2}{*}{ Yeast } & \multicolumn{3}{|c|}{ A. citratum } & \multicolumn{3}{|c|}{ A. daniellii } & \multicolumn{3}{|c|}{ P. capense } & \multicolumn{3}{|c|}{ M. myristica } & \multicolumn{3}{|c|}{ Reference $^{*}$} \\
\hline & MIC & MFC & $\mathbf{R}$ & MIC & MFC & $\mathbf{R}$ & MIC & MFC & $\mathbf{R}$ & MIC & MFC & $\mathbf{R}$ & MIC & MFC & $\mathbf{R}$ \\
\hline C. albicans ATCC 9002 & 256 & 256 & 1 & 512 & 512 & 1 & 512 & 512 & 1 & 512 & 512 & 1 & 0.50 & 1 & 2 \\
\hline C. albicans ATCC 1663 & 1024 & 1024 & 1 & 1024 & 1024 & 1 & 512 & 512 & 1 & 1024 & 1024 & 1 & 2 & 2 & 1 \\
\hline C. parapsilosis & 512 & 1024 & 2 & 512 & 1024 & 1 & 512 & 1024 & 2 & 512 & 1024 & 2 & 0.50 & 1 & 2 \\
\hline C. parapsilosis ATCC 22019 & 1024 & 1024 & 1 & 1024 & 1024 & 1 & 512 & 1024 & 2 & 1024 & 1024 & 1 & 1 & 1 & 1 \\
\hline C. krusei ATCC 6258 & 512 & 1024 & 2 & 2048 & 2048 & 1 & 1024 & 1024 & 1 & 1024 & 1024 & 1 & 0.50 & 1 & 2 \\
\hline C. krusei & 1024 & 1024 & 1 & 256 & 1024 & 4 & 1024 & 1024 & 1 & 512 & 1024 & 1 & 32 & 32 & 1 \\
\hline C. tropicalis ATCC 750 & 1024 & 2048 & 2 & 2048 & 2048 & 1 & 1024 & 1024 & 1 & 1024 & 1024 & 1 & 0.50 & 1 & 2 \\
\hline C. lipolithica & 2048 & 2048 & 1 & 4096 & 4096 & 1 & 512 & 1024 & 2 & 1024 & 1024 & 1 & 0.50 & 1 & 2 \\
\hline C. haemophilus & 256 & 1024 & 4 & 4096 & 4096 & 1 & 512 & 1024 & 2 & 512 & 1024 & 1 & 0.50 & 1 & 2 \\
\hline \multicolumn{16}{|l|}{ Dermatophytes } \\
\hline M. gypseum E1420 & 256 & 4096 & 16 & 4096 & 4096 & 1 & 512 & 512 & 1 & 2048 & 4096 & 2 & 0.50 & 1 & 2 \\
\hline
\end{tabular}


Table 3. Cont

\begin{tabular}{|c|c|c|c|c|c|c|c|c|c|c|c|c|c|c|c|}
\hline T. violaceum & 32 & 1024 & 32 & 128 & 256 & 2 & 512 & 512 & 1 & 2048 & 4096 & 2 & 1 & 1 & 1 \\
\hline
\end{tabular}

MIC: Minimum Inhibitory Concentrations; MFC: Minimum Fungicidal Concentrations; - : not determined; R = MFC/MIC; *Nystatin for yeast and griseofulvin for dermatophytes

Table 4. Antifungal activities (MIC and MFC in $\mu \mathrm{g} / \mathrm{ml}$ ) of essential oils from the tested spices against Candida albicans and Cryptococcus neoformans resistant isolates.

\begin{tabular}{|c|c|c|c|c|c|c|c|c|c|c|c|c|c|c|c|c|c|c|c|c|c|}
\hline \multirow{2}{*}{ Yeasts } & \multicolumn{3}{|c|}{ A. citratum } & \multicolumn{3}{|c|}{ A. danielli } & \multicolumn{3}{|c|}{ P. capense } & \multicolumn{3}{|c|}{ M. myristica } & \multicolumn{3}{|c|}{$A c / A d$} & \multicolumn{3}{|c|}{$\mathrm{Pc} / \mathrm{Mm}$} & \multicolumn{3}{|c|}{ Nystatin } \\
\hline & MIC & MFC & $\mathbf{R}$ & MIC & MFC & $\mathbf{R}$ & MIC & MFC & $\mathbf{R}$ & MIC & MFC & $\mathbf{R}$ & MIC & MFC & $\mathbf{R}$ & MIC & MFC & $\mathbf{R}$ & MIC & MFC & $\mathbf{R}$ \\
\hline \multicolumn{22}{|c|}{ Amphotericin B and nystatin resistant $C$. albicans } \\
\hline Ca Da11 & 128 & 512 & 4 & 1024 & 1024 & 1 & $>4096$ & - & & $>4096$ & - & - & 4096 & 4096 & 1 & $>4096$ & - & - & 16 & 32 & 2 \\
\hline Ca E01 & 512 & 512 & 1 & 1024 & 1024 & 1 & $>4096$ & - & - & $>4096$ & - & - & 4096 & 4096 & 1 & $>4096$ & - & - & 32 & 32 & 1 \\
\hline Ca F021 & 1024 & 1024 & 1 & 2048 & 2048 & 1 & $>4096$ & - & - & 1024 & 1024 & 1 & 4096 & 4096 & 1 & 2048 & - & - & 32 & 128 & 4 \\
\hline Ca F045 & 1024 & 1024 & 1 & 2048 & 2048 & 1 & $>4096$ & - & & $>4096$ & - & - & 4096 & 4096 & 1 & $>4096$ & - & - & 32 & 128 & 4 \\
\hline Ca K42 & 2048 & 2048 & 1 & 2048 & 2048 & 1 & $>4096$ & & - & 2048 & 2048 & 1 & 4096 & 4096 & 1 & $>4096$ & - & - & 32 & 32 & 1 \\
\hline Ca D10 & 4096 & 4096 & 1 & 4096 & 4096 & 1 & 4096 & 4096 & 1 & 4096 & 4096 & 1 & 2048 & 4096 & 2 & 2048 & 2048 & 1 & 16 & 64 & 4 \\
\hline Ca F066 & 4096 & $>4096$ & - & 2048 & - & - & 4096 & - & - & $>4096$ & - & - & 4096 & 4096 & 1 & $>4096$ & - & - & - & - & - \\
\hline Ca F005 & 4096 & 4096 & 1 & $>4096$ & - & - & $>4096$ & - & - & $>4096$ & - & - & 4096 & 4096- & 1 & $>4096$ & - & - & 256 & 256 & 1 \\
\hline Ca F017 & 4096 & 4096 & 1 & $>4096$ & - & - & $>4096$ & - & - & $>4096$ & - & - & 4096 & 4096 & 1 & $>4096$ & & & 32 & 64 & 2 \\
\hline Ca F057 & 4096 & 4096 & 1 & 4096 & 4096 & 1 & 2048 & 2048 & 1 & $>4096$ & - & - & 2048 & 4096 & 2 & $>4096$ & - & - & 128 & 128 & 1 \\
\hline Ca K14 & 512 & 512 & 1 & 1024 & 2048 & 2 & $>4096$ & - & - & $>4096$ & - & - & 512 & 1024 & 2 & $>4096$ & - & - & 64 & 64 & 1 \\
\hline Ca F015 & 1024 & 1024 & 1 & 2048 & 2048 & 1 & $>4096$ & - & - & $>4096$ & - & - & 2048 & 2048 & 1 & $>4096$ & - & & 64 & 64 & 1 \\
\hline $\mathrm{Ca} \mathrm{F023}$ & $>4096$ & - & - & $>4096$ & - & - & $>4096$ & - & - & $>4096$ & - & & 4096 & 4096 & 1 & $>4096$ & - & - & 256 & 256 & 1 \\
\hline $\mathrm{CaF}$ F40 & $>4096$ & - & - & $>4096$ & - & - & $>4096$ & - & - & $>4096$ & - & & 2048 & 4096 & 2 & $>4096$ & - & - & 256 & 256 & 1 \\
\hline Ca F002 & $>4096$ & - & - & $>4096$ & - & - & $>4096$ & - & - & $>4096$ & - & & 4096 & 4096 & 1 & $>4096$ & - & - & 128 & 256 & 2 \\
\hline Ca F041 & 512 & 512 & 1 & 1024 & 1024 & 1 & 4096 & 4096 & 1 & $>4096$ & - & - & 2048 & 2048 & 1 & $>4096$ & - & - & 32 & 128 & 4 \\
\hline Ca K072 & 2048 & 2048 & 1 & $>4096$ & - & - & $>4096$ & - & - & $>4096$ & - & - & 4096 & 4096 & 1 & $>4096$ & - & - & 128 & 256 & 2 \\
\hline Ca F049 & 2048 & - & - & 4096 & - & - & $>4096$ & - & - & $>4096$ & - & - & 2048 & 2048 & 1 & $>4096$ & - & & 128 & 256 & 2 \\
\hline Ca F026 & 2048 & 4096 & 2 & $>4096$ & - & - & $>4096$ & - & - & $>4096$ & & - & 4096 & 4096 & 1 & $>4096$ & - & - & 256 & 256 & 1 \\
\hline Ca K22 & 4096 & - & - & $>4096$ & - & - & $>4096$ & & - & $>4096$ & - & - & 4096 & $>4096$ & - & $>4096$ & - & - & 128 & 256 & 2 \\
\hline \multicolumn{22}{|c|}{ Nystatin resistant $C$. neoformans } \\
\hline $\mathrm{CN}$ & 4096 & 4096 & 1 & $>4096$ & - & - & 4096 & - & - & 4096 & - & - & 2048 & $>4096$ & - & 2048 & - & - & 256 & 256 & 1 \\
\hline CN 169 & 4096 & 4096 & 1 & $>4096$ & - & - & $>4096$ & - & - & $>4096$ & - & - & 4096 & 4096 & 1 & $>4096$ & - & - & 256 & 256 & 1 \\
\hline CN 047 & 1024 & 4096 & 4 & $>4096$ & -- & - & $>4096$ & - & - & $>4096$ & - & - & 4096 & 4096 & 1 & $>4096$ & - & - & 128 & 256 & 2 \\
\hline CN 091 & 4096 & 4096 & 1 & $>4096$ & - & - & $>4096$ & - & - & $>4096$ & - & - & 4096 & $>4096$ & - & $>4096$ & - & - & 256 & 256 & 1 \\
\hline CN 046 & $>4096$ & - & - & $>4096$ & - & - & $>4096$ & - & - & 4096 & - & - & 512 & 512 & 1 & $>4096$ & - & - & 32 & 32 & 1 \\
\hline CN 158 & 4096 & - & - & 4096 & - & - & 1024 & - & - & 4096 & 4096 & 1 & 2048 & 4096 & 2 & $>4096$ & - & - & 128 & 256 & 2 \\
\hline CN 173 & $>4096$ & - & - & $>4096$ & - & - & $>4096$ & - & - & $>4096$ & - & - & 4096 & 4096 & 1 & $>4096$ & - & - & 256 & 256 & 1 \\
\hline CN 096 & 4096 & 4096 & 1 & $>4096$ & - & - & $>4096$ & - & - & $>4096$ & - & - & 4096 & 4096 & 1 & $>4096$ & - & - & 128 & 128 & 1 \\
\hline
\end{tabular}

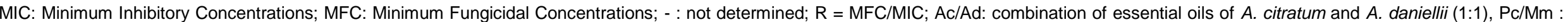
combination of essential oils of $P$. capense and M. myristica (1:1). 

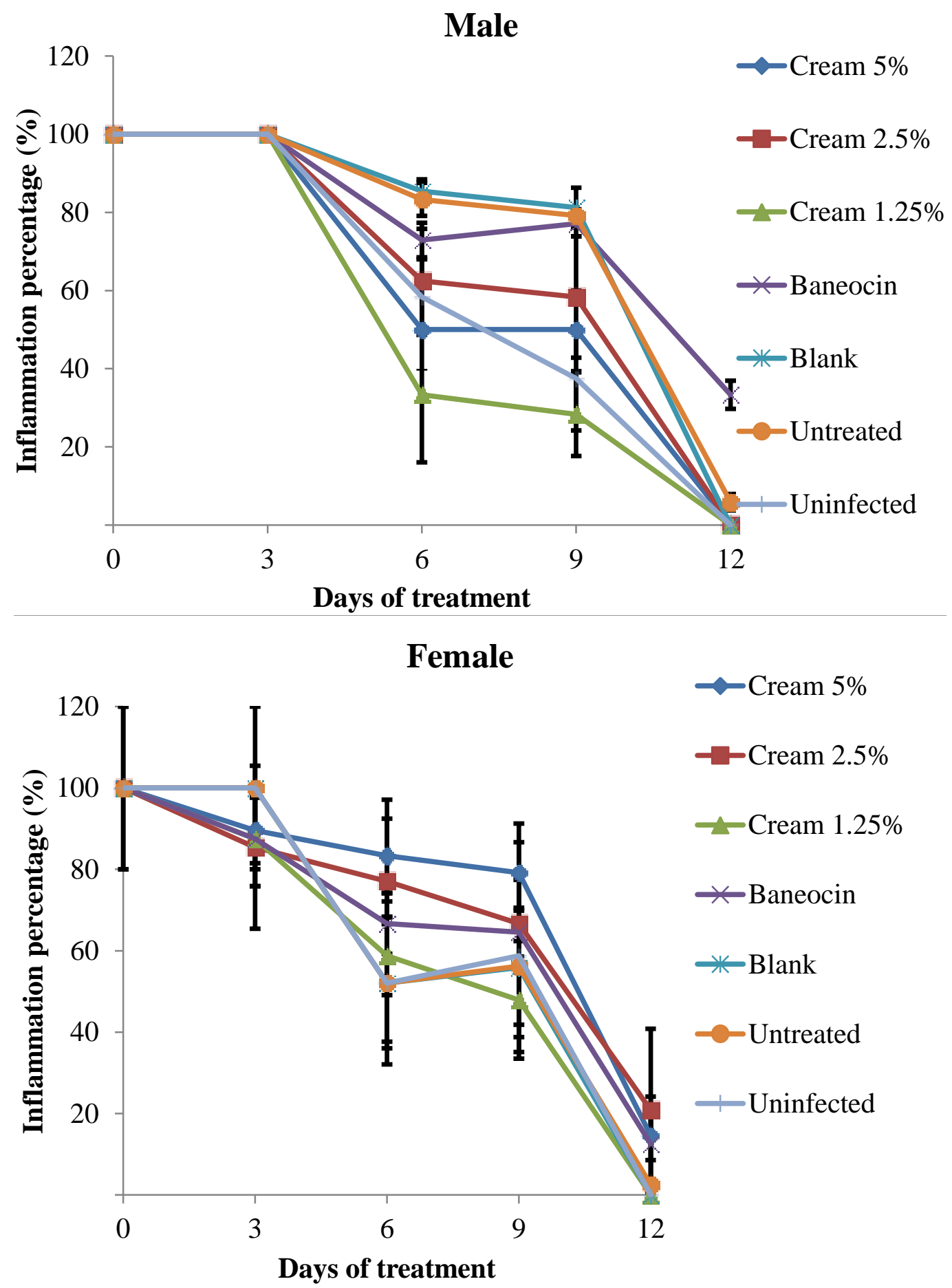

Figure 1. Evolution of the inflammation in male and female rats during the treatment.

the studied essential oils. These differences may be due to the different plant species used. The extraction yield of the essential oil from $A$. citratum seeds is lower than that obtained after $4 \mathrm{~h}$ of hydrodistillation from $A$. citratum seeds (2.8\%) bought at Kribi in Cameroon (Amvam Zollo et al., 2002). The extraction yield of the essential oil from
A. daniellii dried seeds is comparable to that obtained from the fresh seeds of this plant species (1.3\%) collected from Nigeria (Essiens et al., 2017).

The extraction yield from $P$. capense seed $(1.6 \%)$ is slightly similar to that obtained in the literature $(1.98 \%)$ after $3 \mathrm{~h}$ of hydrodistillation from dried ground seeds 


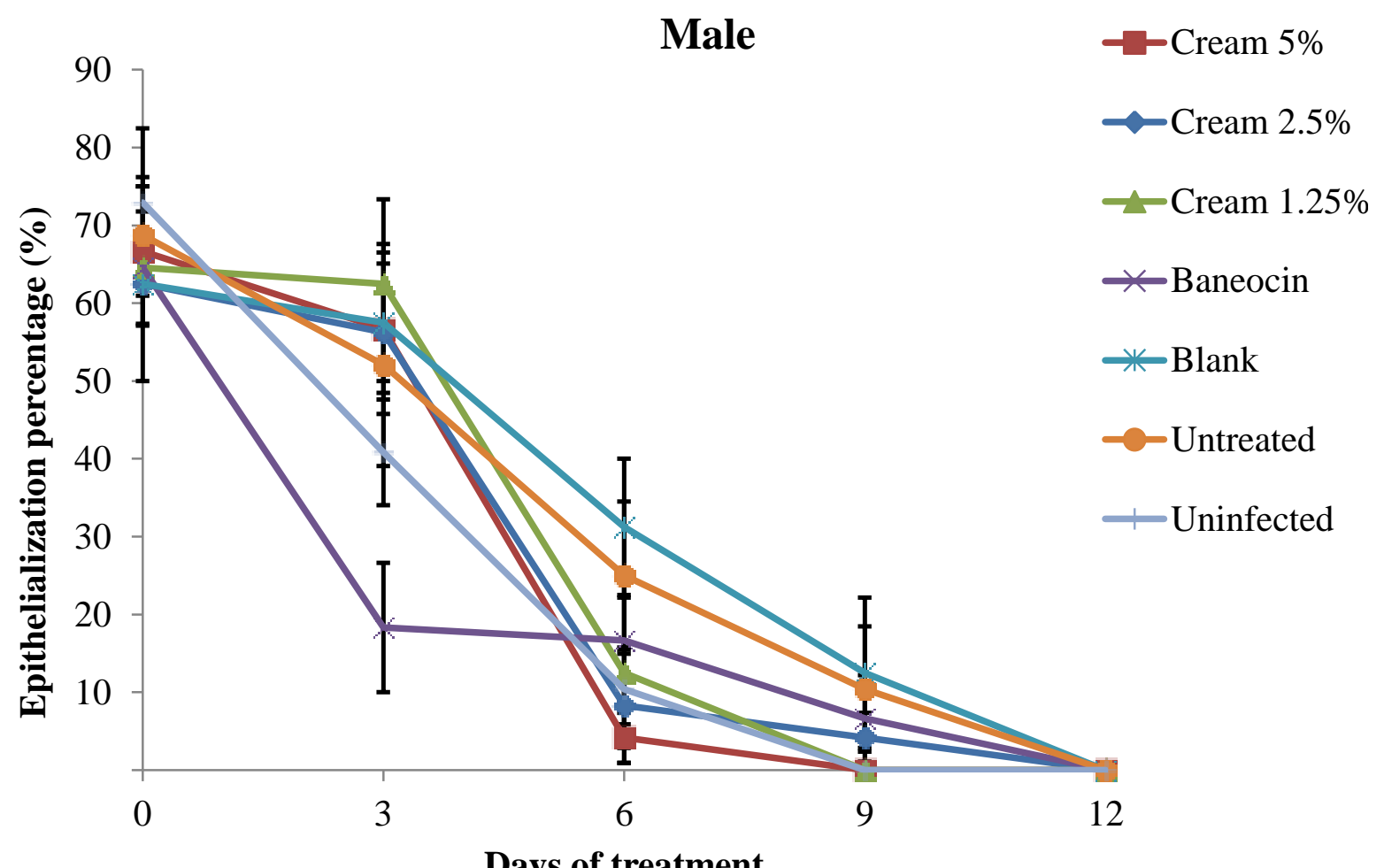

Days of treatment

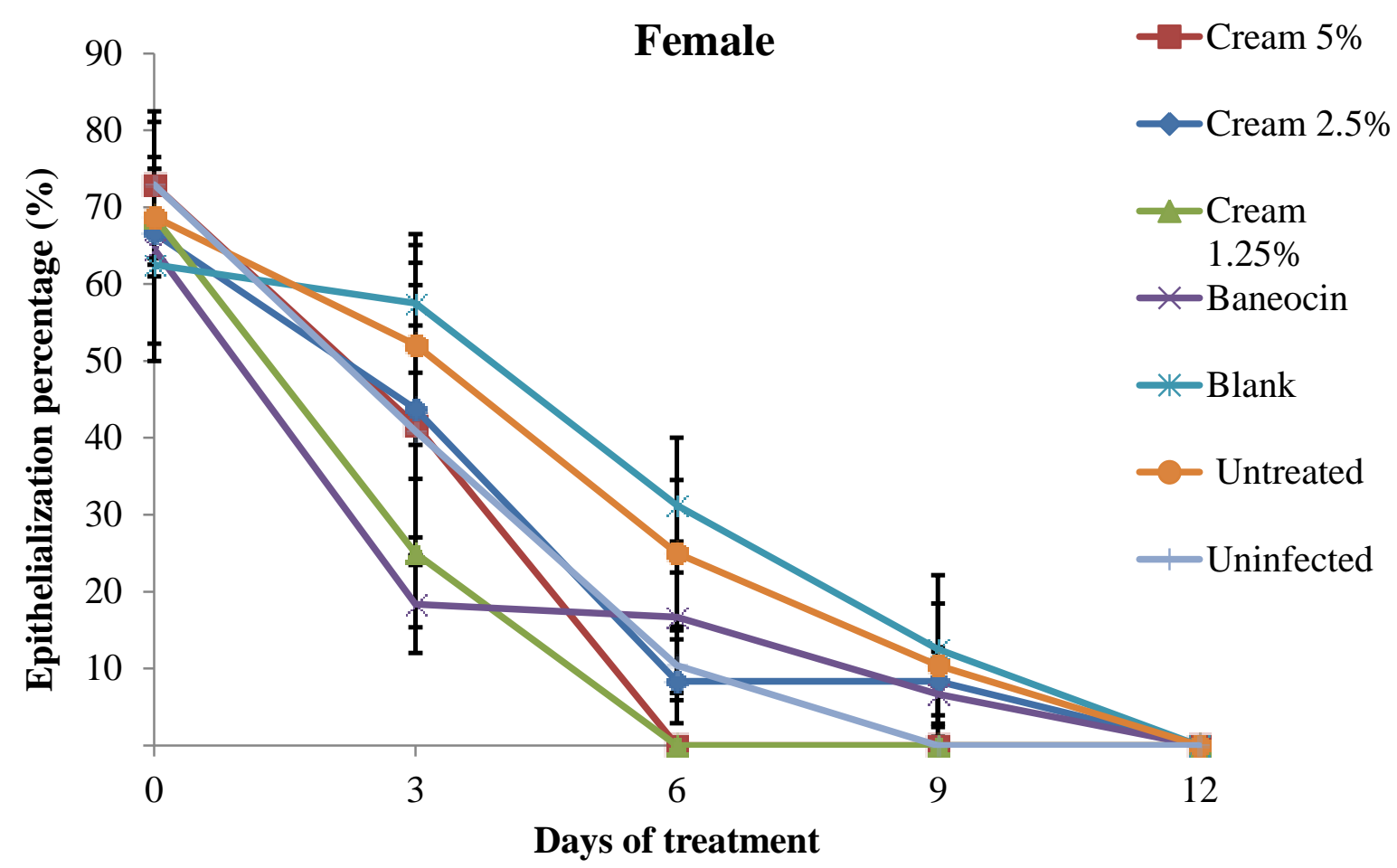

Figure 2. Evolution of epithelialization percentages in male and female rats during the treatment. Bars represent the mean \pm SD of three independent experiments carried out.

(Woguem et al., 2013). This result was also slightly similar with that obtained by Tchoumbougnang et al. (2009), after $5 \mathrm{~h}$ of hydrodistillation (1.51\%). The extraction yield of the essential oil from M. myristica seed $(2.4 \%)$ was higher than that obtained after $7 \mathrm{~h}$ of hydrodistillation of this plant species $(0.21 \%)$, in 
Male

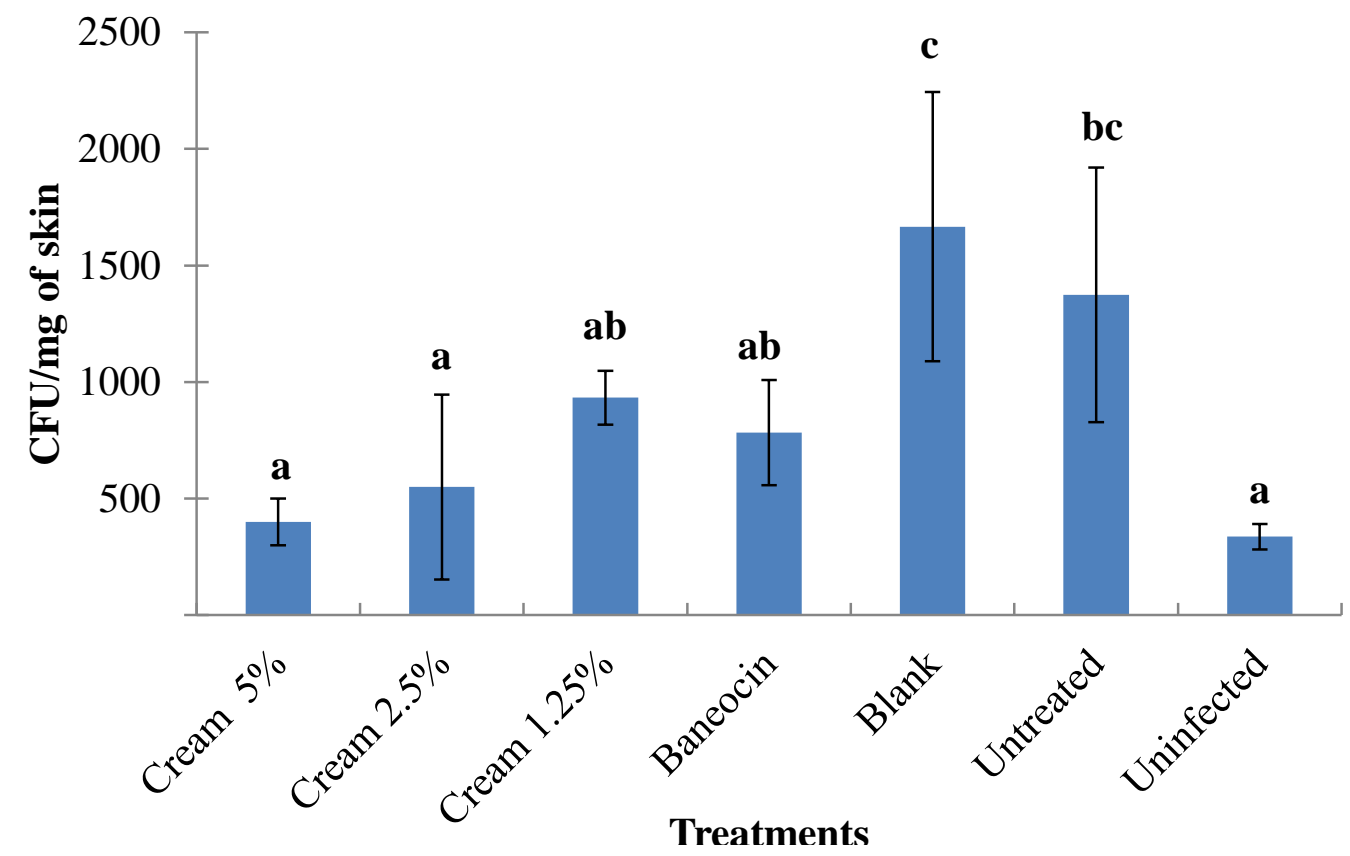

Female

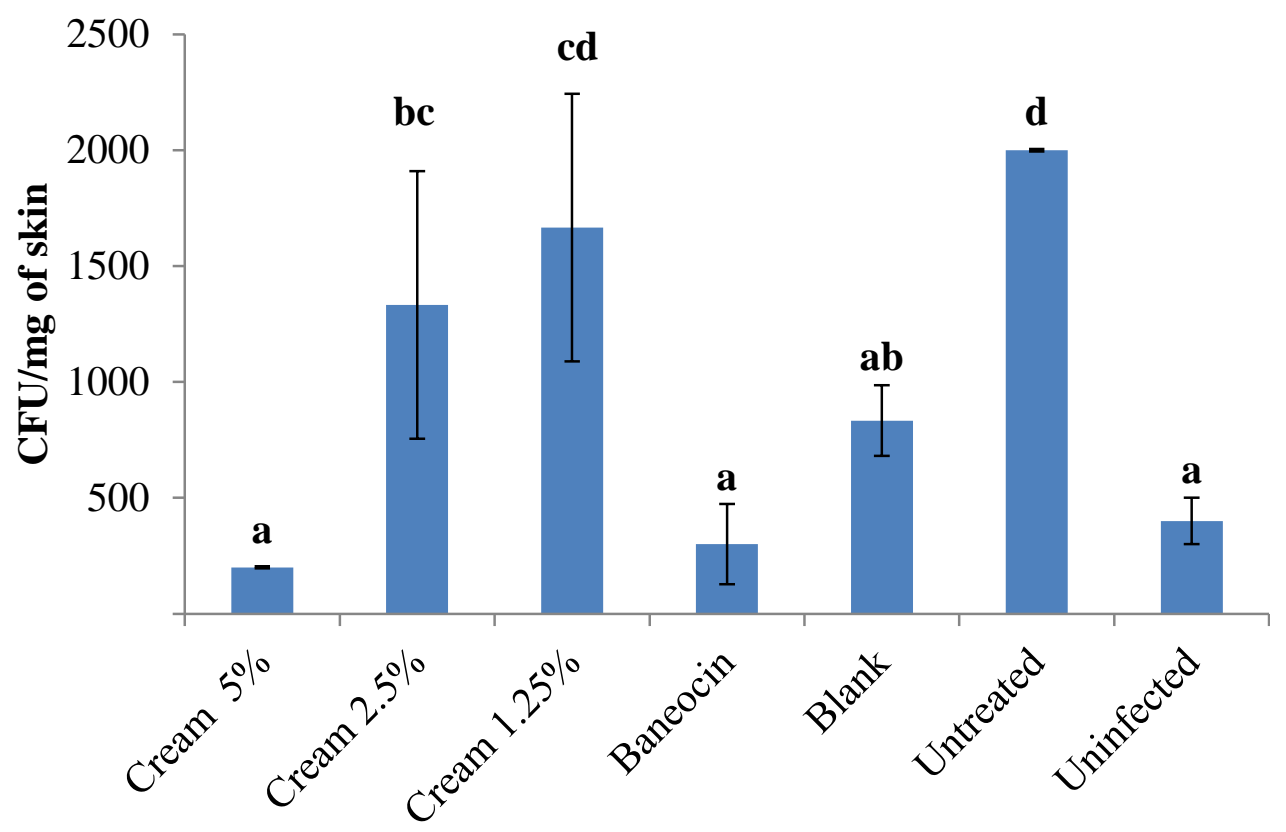

Treatments

Figure 3. Effect of cosmetic cream based on essential oil of $A$. citratum on bacterial load $(\mathrm{CFU} / \mathrm{mg})$ on male and female rats after 14 days of treatment. Bars represent the mean \pm SD of three independent experiments. Letters a-d indicate significant differences between samples according to one way ANOVA and Waller Duncan test; $p<0.05$.

Democratic Republic of Congo (Cimanga et al., 2002). However, this result was comparable to those obtained after $5 \mathrm{~h}$ of hydrodistillation from the same plant species collected in Kribi-Cameroon (2.72\%) and Gore-Chad 
Table 5. Relative organ weight in male and female rats at the end of the treatment.

\begin{tabular}{|c|c|c|c|c|c|c|}
\hline \multirow{2}{*}{ Sex } & \multirow{2}{*}{ Treatment } & \multicolumn{5}{|c|}{ Relative organ weight (g/100 g b.w.) } \\
\hline & & Heart & Lung & Liver & Kidney & Spleen \\
\hline \multirow{7}{*}{ Male } & Cream 5\% & $0.53 \pm 0.05^{\mathrm{a}}$ & $0.94 \pm 0.14^{\mathrm{a}}$ & $5.78 \pm 0.62^{\mathrm{a}}$ & $0.88 \pm 0.14^{\mathrm{a}}$ & $0.57 \pm 0.3^{a}$ \\
\hline & Cream $2.5 \%$ & $0.62 \pm 0.11^{\mathrm{a}}$ & $1.03 \pm 0.08^{\mathrm{a}}$ & $6.52 \pm 0.48^{\mathrm{a}}$ & $1.00 \pm 0.1^{\mathrm{ab}}$ & $0.63 \pm 0.11^{\mathrm{ab}}$ \\
\hline & Cream $1.25 \%$ & $0.52 \pm 0.06^{\mathrm{a}}$ & $0.99 \pm 0.11^{\mathrm{a}}$ & $5.99 \pm 0.78^{\mathrm{a}}$ & $1.05 \pm 0.14^{\mathrm{abc}}$ & $0.31 \pm 0.07^{\mathrm{a}}$ \\
\hline & Baneocin & $0.57 \pm 0.08^{\mathrm{a}}$ & $1.03 \pm 0.17^{\mathrm{a}}$ & $6.38 \pm 0.13^{\mathrm{a}}$ & $1.08 \pm 0.1^{\mathrm{abc}}$ & $0.46 \pm 0.19^{\mathrm{a}}$ \\
\hline & Blank & $0.62 \pm 0.06^{a}$ & $1.09 \pm 0.15^{\mathrm{a}}$ & $7.05 \pm 0.84^{\mathrm{a}}$ & $1.19 \pm 0.1^{b c}$ & $0.98 \pm 0.23^{b c}$ \\
\hline & Untreated & $0.56 \pm 0.02^{\mathrm{a}}$ & $0.96 \pm 0.21^{a}$ & $6.40 \pm 0.57^{\mathrm{a}}$ & $1.08 \pm 0.14^{\mathrm{abc}}$ & $1.09 \pm 0.19^{c d}$ \\
\hline & Uninfected & $0.63 \pm 0.02^{\mathrm{a}}$ & $0.86 \pm 0.02^{\mathrm{a}}$ & $6.64 \pm 0.65^{\mathrm{a}}$ & $1.23 \pm 0.01^{c}$ & $1.41 \pm 0.01^{d}$ \\
\hline \multirow{7}{*}{ Female } & Cream 5\% & $0.41 \pm 0.02^{\mathrm{ab}}$ & $0.84 \pm 0.13^{\mathrm{a}}$ & $5.19 \pm 0.35^{\mathrm{abc}}$ & $0.92 \pm 0.05^{\mathrm{a}}$ & $0.53 \pm 0.1^{\mathrm{abc}}$ \\
\hline & Cream $2.5 \%$ & $0.41 \pm 0.03^{\mathrm{ab}}$ & $0.80 \pm 0.06^{\mathrm{a}}$ & $4.68 \pm 0.8^{\mathrm{abc}}$ & $0.90 \pm 0.06^{\mathrm{a}}$ & $0.46 \pm 0.06^{\mathrm{ab}}$ \\
\hline & Cream $1.25 \%$ & $0.47 \pm 0.03^{\mathrm{abc}}$ & $0.98 \pm 0.21^{\mathrm{a}}$ & $5.00 \pm 0.49^{\mathrm{ab}}$ & $1.00 \pm 0.08^{\mathrm{a}}$ & $0.51 \pm 0.07^{\mathrm{abc}}$ \\
\hline & Baneocin & $0.32 \pm 0.23^{\mathrm{a}}$ & $0.60 \pm 0.43^{\mathrm{a}}$ & $3.92 \pm 2.89^{\mathrm{a}}$ & $0.81 \pm 0.6^{\mathrm{a}}$ & $0.41 \pm 0.31^{\mathrm{a}}$ \\
\hline & Blank & $0.61 \pm 0.08^{c}$ & $1.11 \pm 0.36^{\mathrm{a}}$ & $6.52 \pm 0.71^{\mathrm{bc}}$ & $1.21 \pm 0.12^{\mathrm{a}}$ & $1.00 \pm 0.12^{\mathrm{bc}}$ \\
\hline & Untreated & $0.59 \pm 0.01^{\mathrm{bc}}$ & $1.02 \pm 0.02^{\mathrm{a}}$ & $7.32 \pm 0.81^{c}$ & $1.29 \pm 0.15^{\mathrm{a}}$ & $1.03 \pm 0.59^{c}$ \\
\hline & Uninfected & $0.57 \pm 0.02^{\mathrm{bc}}$ & $1.00 \pm 0.05^{\mathrm{a}}$ & $6.24 \pm 0.04^{\mathrm{abc}}$ & $1.18 \pm 0.03^{\mathrm{a}}$ & $0.44 \pm 0.13^{\mathrm{a}}$ \\
\hline
\end{tabular}

Data represent the mean $\pm S D$ of three independent experiments. For the same organ and sex, letters a-d indicate significant differences between samples according to one way ANOVA and Waller Duncan test; $p<0.05$.

(1.87\%) (Bakarnga-Via et al., 2014). The differences in the extraction yields and those in the literature may be due to the place and period of harvesting of the plant, the variety of plant species used, the duration of extraction, the environmental variations (Zheljazkov et al., 2015).

The findings of the present study showed that the essential oil of $A$. citratum seeds was mainly composed of monoterpene with a predominance of oxygenated monoterpenes (geraniol, 96.80\%) and the absence of sesquiterpenes. These results are in agreement with those of Amvam Zollo et al. (2002) who obtained an essential oil consisting mainly of oxygenated monoterpenes with a predominance of geraniol $(70 \%)$. The results of the chemical composition of essential oils from $A$. daniellii seeds were in agreement with those of the early reports. Indeed, Essien et al. (2017) reported a high content of 1,8 -cineole $(53.4 \%)$, a-terpineol (12.2\%) and $\beta$-pinene $(9.1 \%)$ in the essential oil from $A$. danielli seeds whereas the main compounds identified from the essential oils of this plant collected in Sao Tome were 1,8-cineole (25.5-34.4\%), $\beta$-pinene (14.1-15.2\%) and $\alpha$ terpineol (9.9-12.1\%) (Martins et al., 2001). Moreover, Adegoke et al. (1998) recorded 1,8-cineole (59.8\%), $\beta$ pinene $(13.2 \%)$ and $\alpha$-terpineol $(9.3 \%)$ in high proportions in the same essential oil from Nigeria, while 1,8-cineole $(48.9 \%)$ was the main compound of $A$. danielli seeds collected in Cameroon (Menut et al., 1991).

The chemical composition of the essential oil of $P$. capense seed was comparable to those reported in the literature (Woguem et al., 2013, Amvam Zollo et al., 1998, Tchounbougnang et al., 2009). Indeed, previous study showed that essential oil obtained from $P$. capense seed is mainly constituted by monoterpenes $(64.7 \%)$ with predominance of hydrocarbons (56.5\%). Major constituents were monoterpene hydrocarbons: $\alpha$-pinene $(8.9 \%)$, sabinene $(10.0 \%), \quad \beta$-pinene $(33.2 \%)$ and sesquiterpene hydrocarbons: $\alpha$-caryophyllène $(6.3 \%)$ and germacrene D (3.8\%) (Woguem et al., 2013). Other studies also reported that major volatile compounds of fruits from Western Cameroon were monoterpene hydrocarbons: $\alpha$-pinene $(10.5-14.4 \%)$, sabinene (14.7$17.4 \%), \quad \beta$-pinene $(46.8-59.3 \%)$ and sesquiterpene hydrocarbons: (E)-caryoplyllene (3.4-4.0\%) and germacrene D (2.5-5.2\%) (Amvam Zollo et al., 1998; Tchoumbougnang et al., 2009).

However, the extraction yields were slightly different with respect to those obtained in this study. The results of the chemical composition of essential oils of $M$. myristica seeds are comparable to those of Bakarnga-Via et al. (2014), who found $67.1 \%$ of $\alpha$-phellandrene and $4.2 \%$ of a-pinene in a sample collected from Kribi (Cameroon) and $52.7 \%$ of $\alpha$-phellandrene and $14.9 \%$ of limonene in a sample collected from Gore (Chad). Our results are also in agreement with those of Lamaty et al. (1987), who found $48.8 \%$ of $\alpha$-phellandrene in a sample collected in Yaounde (Cameroon); however, the extraction yields were slightly different.

Differences in antimicrobial activity were noted between the studied essential oils. These differences may be due to the different phytoconstituents identified in these essential oils. Indeed, the antimicrobial activities of medicinal plants are correlated with the presence in their extracts of one or more classes of bioactive secondary metabolites (Reuben et al., 2008).

According to established criteria, MIC values in the range of $100-1000 \mu \mathrm{g} / \mathrm{ml}$ are indications that botanicals 
have antimicrobial activities (Simoes et al., 2009). Also antimicrobial activity of edible plant extracts or extracts from edible parts of plants is considered highly active if MIC values are below $100 \mu \mathrm{g} / \mathrm{ml}$, significantly active if $100 \leq \mathrm{MIC} \leq 512 \mu \mathrm{g} / \mathrm{ml}$, moderately active if $512<\mathrm{MIC} \leq$ $2048 \mu \mathrm{g} / \mathrm{ml}$, low activity if MIC $>2048 \mu \mathrm{g} / \mathrm{ml}$ and not active if MIC > $10000 \mu \mathrm{g} / \mathrm{ml}$ (Tamokou et al., 2017).

Amongst essential oils that showed the highest activities (MICs $<100 \mu \mathrm{g} / \mathrm{ml}$ ), there are essential oil of $A$. citratum against $S$. aureus, $S$. aureus MSSA01, $S$. aureus MRSA03, S. aureus MRSA04, B. subtilis, E. coli S2(1), entero-aggregative $E$. coli and $P$. aeruginosa ATCC 27853; essential oil of $A$. daniellii against $S$. aureus ATCC 25923, S. aureus MSSA01, S. aureus MRSA04, E. coli S2(1) and $P$. aeruginosa ATCC 27853; essential oil of $P$. capense against $S$. aureus ATCC 25923, B. subtilis and $P$. aeruginosa ATCC 27853 and essential oil of $M$. myristica against $E$. coli S2(1) and $P$. aeruginosa ATCC 27853.

The results of antimicrobial activities of $A$. citratum, $P$. capense, A. daniellii and $M$. myristica clearly indicate that the essential oils from these plants have antibacterial and antifungal properties. These data corroborate those of the previous works (Tatsadjieu et al., 2003; Fasoyiro and Adegoke, 2007; Steenkamp et al., 2007; Samie et al., 2010). Collectively, the present study showed that the tested essential oils have antimicrobial activities and are effective against methicillin resistant $S$. aureus, amphotericin B and nystatin resistant Candida albicans and Cryptococcus neoformans. The overall results of the present investigation confirmed the traditional uses of the studied spices in the treatment of microbial infections. Taking into account the medical importance of the tested microorganisms, this result can be considered as promising in the perspective of developing new antimicrobial agents from plant origin. During the MIC and MMB determination, we have noted that MMC values are in general fourfold lesser than the MIC values on the corresponding microorganism; suggesting that the studied essential oils have a microbicidal effect on the sensitive microorganisms (Mims et al., 1993).

Combinations of antibiotics can lead to synergistic effects especially during the therapy of fungal infections. These combinations have been recognized as being able to delay the emergence of resistant strains of microorganisms (Aiyegoro and Okoh, 2009). The effect of synergy between plant-derived essential oils makes it possible to use essential oils when their efficacy alone is reduced (Nascimento et al., 2000). These observations could explain the evaluation of the antifungal activity of the combination of essential oils of the studied plants, because in addition to substances having direct antifungal activity, it has been demonstrated that within plants, other substances can act as adjuvants by modulating the activity of antifungal agents (Veras et al., 2012). The antifungal activities of the combination of essential oils of $A$. citratum and $A$. daniellii (1:1) were greater than those of these essential oils used alone. However, the combination of essential oils of $P$. capense and $M$. myritica (1:1) reduced their antifungal activities compared to those of these essential oils used alone. The above findings suggest that the combination of essential oils of $A$. citratum and $A$. daniellii (1:1) has synergistic effect, whereas the combination of essential oils of $P$. capense and $M$. myritica (1:1) has an antagonistic effect. The monoterpene and sesquiterpene compounds found in these essential oils would be responsible for the observed effects with respect to certain $C$. albicans and $C$. neoformans resistant isolates.

The results of the therapeutic effect of the cream based on essential oil of $A$. citratum seeds against dermatosis induced with methicillin resistant $S$. aureus in rats revealed that epithelialization time was significantly shorter in animals treated with cream based on essential oil of $A$. citratum compared to negative control groups. Indeed, epithelialization involves the proliferation and migration of epithelial cells through the wound bed (Sanwal and Chaudhary, 2011). Therefore, a shorter epithelialization time could be due to facilitated epithelial cell proliferation and/or increased viability of epithelial cells (Mulisa et al., 2015).

Thus, the shorter epithelialization time in the animals treated with the essential oil reinforce the hypothesis according to which the essential oil of $A$. citratum has a potential application as an antibacterial healing agent. Moreover, the fact that the cream based on essential oil of $A$. citratum significantly reduced the number of Colony Forming Units (CFU) of bacteria at the infection site compared to the negative controls also supports the in vivo antibacterial properties of $A$. citratum essential oil. To the best of our knowledge, this is the first report on the therapeutic effect of the essential oil from $A$. citratum.

\section{Conclusion}

The overall results of the present investigation indicated that the main compounds identified in the essential oils are geraniol $(98 \%)$ for $A$. citratum; eucalyptol (48.8\%), $\alpha$ terpineol $(21.7 \%)$ and geraniol $(10.5 \%)$ for $A$. daniellii; $\beta$ pinene $(37.3 \%)$, germacrene D $(9.8 \%)$, trans- $\beta$ caryophyllene $(8.8 \%)$, $\alpha$-pinene $(8.6 \%)$, naphthalene $(8.3 \%)$ and sabinene $(4.8 \%)$ for $P$. capense; $\alpha-$ phellandrene $(61.5 \%)$, germacradienol $(7.9 \%)$ and $\delta$ cadinene $(4.2 \%)$ for M. myristica. The tested essential oils possess antimicrobial activities which could be a function of either the individual or the additive effects of the identified volatile components. The cream based on essential oil of $A$. citratum (5\%) can be used in the treatment of dermatosis induced with MRSA subject to further toxicological and pre-clinical studies.

\section{CONFLICT OF INTERESTS}

The authors have not declared any conflict of interests. 


\section{ACKNOWLEDGMENT}

The authors are particularly grateful to Prof. Dzoyem Jean Paul for providing resistant isolates of yeasts for the partial realization of the antifungal activity.

\section{REFERENCES}

Adegoke GO, Rao JM, Shankaracharya NB (1998). A comparison of the essential oils of Aframomum daniellii (Hook. F.) K. Schum. and Amomum subulatum Roxb. Flavour and Fragrance Journal 13(5):349-352.

Aiyegoro OA, Okoh A I (2009). Use of bioactive plant products in combination with standard antibiotics: implications in antimicrobial chemotherapy. Journal of Medicinal Plants Research 3(13):11471152.

Ameri A, Rajive BB, Vaidya JG, Apte K, Deokule SS (2013). AntiStaphylococcal and wound healing activities of Ganoderma praelongum and Glycyrrhiza glabra formulation in mice. International Journal of Applied Research in Natural Products 6(1):27-31.

Amvam Zollo P, Abondo R, Biyiti L, Menut C, Bessière J (2002). Aromatic plants of Tropical Central Africa XXXVIII: Chemical composition of the essential oils from four Aframomum species collected in Cameroon (1). Journal of Essential Oil Research 14(2):95-98

Amvam Zollo PH, Biyiti L, Tchoumbougnang F, Menut C, Lamaty G, Bouchet P (1998). Aromatic plants of tropical central Africa. Part XXXII. Chemical composition and antifungal activity of thirteen essential oils from aromatic plants of Cameroon. Flavour and Fragrance Journal 13(2):107-114.

Bakarnga-via I, Hzounda JB, Fokou PV, Tchokouaha LRY, Gary-Bobo M, Gallud A, Garcia M, Walbadet L, Secka Y, Dongmo PMJ, Boyom FF, Menut C (2014). Composition and cytotoxic activity of essential oils from Xylopia aethiopica (Dunal) A. Rich, Xylopia parviflora (A. Rich) Benth.) and Monodora myristica (Gaertn) growing in Chad and Cameroon. BMC Complementary and Alternative Medicine 14:125.

Banker GS, Rhodes CT (1995). Modern pharmaceutics-drug and the pharmaceutical sciences. New York, N.Y: Marcel Dekker Inc. NY Publications. pp. 278-279.

Burkil HM (2000). The Useful Plants of West Tropical Africa. $2^{\text {nd }}$ edition, volume 5, Fa milies $S-Z$, Royal Botanic Gardens. Kew, Richmond, United Kingdom P 686.

Cimanga K, Kambu K, Tona L, Apers S, De Bruyne T, Hermans N, Totte J, Pieters L, Vlietinck AJ (2002). Correlation between chemical composition and antibacterial activity of essential oils of some aromatic medicinal plants growing in the Democratic Republic of Congo. Journal of Ethnopharmacology 79(2):213-220.

Dzoyem JP, Tchuenguem R, Kuiate JR, Teke GN, Kechia A, Kuete V (2014). In vitro and In vivo antifungal activities of selected Cameroonian dietary spices. BMC Complementary and Alternative Medicine 14:58

Essien EE, Thomas PS, Oriakhi K, Choudhary MI (2017). Characterization and antioxidant activity of volatile constituents from different parts of Aframomum danielli (Hook) K. Schum. Medicines 4:29.

Fasoyiro SB, Adegoke GO (2007). Phytochemical characterization and the antimicrobial property of Aframomum danielli extract. African Journal of Agricultural Research 2(3):76-79.

Fernandes CP, Mascarenhas MP, Zibetti FM, Lima BG, Oliveira RRF, Rocha L, Falcão DQ (2013). HLB value, an important parameter for the development of essential oil phytopharmaceuticals. Revista Brasileira de Farmacognosia 23(1):108-114.

Focho DA, Ndam WT, Fonge BA (2009). Medicinal plants of AguambuBamumbu in the Lebialem highlands, South West province of Cameroon. African Journal of Pharmacology 3(1):001-013.

Fogue PS, Lunga PK, Fondjo ES, Tamokou JD, Boudjeko T, Tsemeugne J, Amandine T, Tienga A, Kuiate JR (2012). Substituted 2-aminothiophenes: antifungal activities and effect on Microsporum gypseum protein profile. Mycoses 55(4):310-317.
Kokwaro J (1976). Medicinal Plants of East Africa. East African Literature Bureau, Kampala, Uganda. Third Edition. University of Nairobi Press. 478p.

Kuete V, Krusche B, Youns M, Voukeng I, Fankam AG, Tankeo S, Lacmata S, Efferth T (2011). Cytotoxicity of some Cameroonian spices and selected medicinal plant extracts. Journal of Ethnopharmacology 134(3):803-812.

Kugelberg E, Norström T, Petersen TK, Duvold T, Andersson DI, Hughes D (2005). Establishment of a superficial skin infection model in mice by using Staphylococcus aureus and Streptococcus Pyogenes. Antimicrobial Agents and Chemotherapy 8(49):34353441.

Lamaty G, Menut C, Bessiere JM, Amvam Zollo PH, Fekam BF (1987). Aromatic plants of tropical central Africa. I. Volatile components of two Annonaceae from Cameroon: Xylopia aethiopica (dunal) A. Richard and Monodora myristica (Gaertn.) Dunal. Flavour and Fragrance Journal 2(3):91-94.

Lee MS, Choi J, Posadzki P, Ernst E (2012). Aromatherapy for health care: An overview of systematic reviews. Maturitas 71(3):257-260.

Malachowa N, Kobayashi SD, Braughton KR, DeLeo FR (2013). Mouse model of Staphylococcus aureus skin infection. In Mouse Models of Innate Immunity (pp. 109-116). Humana Press, Totowa, NJ.

Martins AP, Salgueiro L, Gongalves MJ, da Cunha AP, Vila R, Canigueral S, Mazzoni V, Tomi F, Casanova J (2001). Essential oils composition and antimicrobial activity of three Zingiberaceae from Sao Tome and Principe. Planta Medica 67(6):580-584.

Menut C, Lamaty G, Amvan Zollo PH, Atoho BM, Abondo R, Bessiere JM (1991). Aromatic plants of tropical Central Africa. Volatile components of three Zingiberaceae from Cameroon: Aframomum melegueta (roscoe) K. Schum., A. Daniellii (Hook. f.) K. Schum. and A. Sulcatum (Oliv. and Hanb.) K. Schum. Flavour and Fragrance Journal 6(3):183-186.

Millikan LE (2002). Complementary medicine in dermatology. Clinics in Dermatology 20(5):602-605.

Mims CA, Playfair JHL, Roitt IM, Wakelin D, Williams R (1993). Antimicrobials and chemotherapy. In: Mims CA et al. (Eds.). Medical Microbiology Review 35:1-34.

Mith H, Duré R, Delcenserie V, Zhiri A, Daube G, Clinquart A (2014). Antimicrobial activities of commercial essential oils and their components against food-borne pathogens and food spoilage bacteria. Food Science and Nutrition 2(4):403-416.

Mulisa E, Asres K and Engidawork E (2015). Evaluation of wound healing and anti-inflammatory activity of the rhizomes of Rumex abyssinicus J. (Polygonaceae) in mice. BMC Complementary and Alternative Medicine 15:341.

Nascimento GGF, Locatelli J, Freitas PC, Silva GL (2000). Antibacterial activity of plant extracts and phytochemicals on antibiotic-resistant bacteria. Brazilian Journal of Microbiology 31(4):247-256

Pamela R, Maggi $F$, Mbuntcha $\mathrm{H}$, Woguem V, Fongang DPH, Womeni MH, Tapondjou AL, Barboni L, Nicoletti M, Canale A, Benelli G (2016). Traditional herbal remedies and dietary spices from Cameroon as novel sources of larvicides against filariasis mosquitoes. Parasitology Research 115(12):4617-4626.

Rahman S, Parvez AK, Islam R, Khan MH (2011). Antibacterial activity of natural spices on multiple drug resistant Escherichia coli isolated from drinking water, Bangladesh. Annals of Clinical Microbiology and Antimicrobials 10:10.

Reichling J, Schnitzler P, Suschke U, Saller R (2009). Essential oils of aromatic plants with antibacterial, antifungal, antiviral, and cytotoxic properties-an overview. Research in Complementary Medicine 16(2):7990.

Reuben KD, Abdulrahman FI, Akan JC, Usman H, Sodipo OA, Egwu GO (2008). Phytochemical screening and in vitro antimicrobial investigation of the methanolic extract of Croton Zambesicus Muell ARG. stem bark. European Journal of Scientific Research 23(1):134140

Samie A, Tambani T, Harshfield E, Green E, Ramalivhana E, Bessong PO (2010). Antifungal activities of selected Venda medicinal plants against Candida albicans, Candida krusei and Cryptococcus neoformans isolated from South African AIDS patients. African Journal of Biotechnology 9(20):2965-2976.

Sanwal R, Chaudhary AK (2011). Wound healing and antimicrobial 
potential of Carissa spinarum Linn. in albino mice. Journal of Ethnopharmacology 135(3):792-796.

Simoes M, Bennett RN, Rosa EAS (2009). Understanding antimicrobial activities of phytochemicals against multidrug resistant bacteria and bioflms. Natural Product Reports 26(6):746-757.

Song M, Zeng Q, Xiang Y, Gao L, Huang J, WU K, Lu J (2017). The antibacterial effect of topical ozone on the treatment of MRSA skin infection. Molecular Medicine Reports 17(2):2449-2455.

Steenkamp V, Fernandes AC, van Rensburg CEJ (2007). Antibacterial activity of Venda medicinal plants. Fitoterapia 78(7-8):561-564.

Tajkarimi MM, Ibrahim SA, Cliver DO (2010). Antimicrobial herb and spice compounds in food. Food Control 21(9):1199-1218.

Tamokou JDD, Mbaveng TA, Kuete V (2017). Antimicrobial activities of African medicinal spices and vegetables. In Medicinal Spices and Vegetables from Africa. Academic Press pp. 207-237.

Tamokou JDD, Tala FM, Wabo KH, Kuiate JR, Tane P (2009). Antimicrobial activities of methanol extract and compounds from stem bark of Vismia rubescens. Journal of Ethnopharmacology 124(3):571575.

Tatsadjieu LN, Essia Ngang JJ, Ngassoum MB, Etoa F-X (2003). Antibacterial and antifungal activity of Xylopia aethiopica, Monodora myristica, Zanthoxylum xanthoxyloıdes and $Z$. leprieurii from Cameroon. Fitoterapia 74(5):469-472.

Tchoumbougnang F, Jazet DPM, Sameza ML, Fombotioh N, Wouatsa NAV, Amvam ZPH, Menut C (2009). Comparative essential oils composition and insecticidal effect of different tissues of Piper capense L., Piper guinense Schum. et Thonn., Piper nigrum L., and Piper umbellatum L., grown in Cameroon. African Journal of Biotechnology 8(3):424-431.

Titanji VPK, Zofou D, Ngemenya MN (2008). The antimalarial potentia of medicinal plants used for the treatment of malaria in Cameroonian folk medicine. African Journal of Traditional, Complementary, and Alternative Medicines 5(3):302.

Van Wyk B, Gericke N (2000). Peoples Plants: A Guide to Useful Plants in Southern Africa. Briza Publications, Pretoria, South Africa $352 \mathrm{p}$.

Veras HNH, Rodrigues FFG, Colares AV, Menezes IRA, Coutinho HDM, Botelho MA, Costa JGM (2012). Synergistic antibiotic activity of volatile compounds from the essential oil of Lippia sidoides and thymol. Fitoterapia 83(3):508-512.
Woguem V, Maggi F, Fogang HPD, Tapondjou LA, Womeni HM, Quassinti L, Bramucci M, Vitali LA, Petrelli D, Lupidi G, Vittori S, Barboni L (2013). Antioxidant, antiproliferative and antimicrobial activities of the volatile oil from the wild pepper Piper capense used in Cameroon as a culinary spice. Natural Product Communications 8(12):1791-1796.

Yang X, Zhang J, Yu S, Wu Q, Guo W, Huang J, Cai S (2016). Prevalence of Staphylococcus aureus and methicillin-resistant Staphylococcus aureus in retail ready-to-eat foods in China. Frontiers in Microbiology 7:816.

Zheljazkov VD, Shiwakoti S, Astatkie T, Salamon I, Grul'ová D, Mudrencekova S, Schlegel V (2015). Yield, composition, and antioxidant capacity of ground cumin seed oil fractions obtained at different time points during the hydrodistillation. Horticultural Science 50(8):1213-1217. 